\title{
CRY1 wt Allele
}

National Cancer Institute

\section{Source}

National Cancer Institute. CRY1 wt Allele. NCI Thesaurus. Code C101344.

Human CRY1 wild-type allele is located within 12q23-q24.1 and is approximately $103 \mathrm{~kb}$ in length. This allele, which encodes cryptochrome-1 protein, is involved in the regulation of circadian rhythm. 